\title{
From Player to Pawn: Viral Avirulence Factors Involved in Plant Immunity
}

\author{
Changjun Huang
}

check for

updates

Citation: Huang, C. From Player to Pawn: Viral Avirulence Factors Involved in Plant Immunity. Viruses 2021, 13, 688. https://doi.org/ $10.3390 / v 13040688$

Academic Editor: Feng Qu

Received: 18 March 2021

Accepted: 14 April 2021

Published: 16 April 2021

Publisher's Note: MDPI stays neutral with regard to jurisdictional claims in published maps and institutional affiliations.

Copyright: (C) 2021 by the author. Licensee MDPI, Basel, Switzerland. This article is an open access article distributed under the terms and conditions of the Creative Commons Attribution (CC BY) license (https:/ / creativecommons.org/licenses/by/ $4.0 /)$.
Key Laboratory of Tobacco Biotechnological Breeding, National Tobacco Genetic Engineering Research Center, Yunnan Academy of Tobacco Agricultural Sciences, Kunming 650021, China; cjhuang@zju.edu.cn; Tel.: +86-877-2075024

\begin{abstract}
In the plant immune system, according to the 'gene-for-gene' model, a resistance $(R)$ gene product in the plant specifically surveils a corresponding effector protein functioning as an avirulence (Avr) gene product. This system differs from other plant-pathogen interaction systems, in which plant $R$ genes recognize a single type of gene or gene family because almost all virus genes with distinct structures and functions can also interact with $R$ genes as Avr determinants. Thus, research conducted on viral Avr-R systems can provide a novel understanding of Avr and $R$ gene product interactions and identify mechanisms that enable rapid co-evolution of plants and phytopathogens. In this review, we intend to provide a brief overview of virus-encoded proteins and their roles in triggering plant resistance, and we also summarize current progress in understanding plant resistance against virus Avr genes. Moreover, we present applications of Avr gene-mediated phenotyping in $R$ gene identification and screening of segregating populations during breeding processes.
\end{abstract}

Keywords: plant viruses; plant immunity; NB-LRR; avirulence gene; effector-triggered immunity (ETI); viral effectors

\section{Introduction}

Plant viruses contain single-stranded or double-stranded RNA or DNA genomes and vary substantially in their genome structure and organization. Moreover, limited viral genome sizes and coding capacities have resulted in evolution of multifunctional proteins that are involved in different steps in the virus life cycle, including replication, movement, encapsidation and transmission. On the other hand, as obligate intracellular parasites, plant viruses absolutely depend on the host cell machinery to multiply, move throughout the plant and spread to susceptible hosts. During infection, viruses consume a substantial amount of host resources; subsequently, disease symptoms develop as a consequence of disruptions of the cellular machinery required for plant physiology and natural growth, and these disruptions eventually result in developmental abnormalities and other phenotypic manifestations. Viruses can be critical players in pathogenesis through direct or indirect interactions. However, in some plant species or varieties, virus-encoded proteins can sometimes act as determinants in plant defense responses and as host-controlled pawns to elicit extreme resistance (ER).

According to the zigzag model of plant-pathogen interactions, the plant innate immune system is broadly divided into two different layers: pathogen-associated molecular pattern (PAMP)-triggered immunity (PTI) and effector-triggered immunity (ETI) [1]. PTI is activated by specific recognition between PAMPs, such as bacterial flagellin and fungal chitin, and the corresponding membrane-anchored pattern recognition receptors (PRRs) of plants, which serve as the first layer of defense against invading pathogens. Plant viruses were historically viewed as non-PAMP coding pathogens and plant antiviral immunity was previously excluded from classical PTI models. However, recent evidence shows that PTI also operates against viruses in plants: For example, novel paradigms in antiviral immunity include (I) identification of dsRNAs and viral nucleic acids as PAMPs [2,3]; (II) 
plant virus effects on cell wall remodeling that imply that virus infections can modulate damage-associated molecular patterns (DAMPs) pathways with molecular mechanisms similar to PTI [4-7]; (III) several PRRs, e.g., NIK1, BAK1, BIR1, BKK1 (BAK1-Like 1) and Serk1 that have been shown to have roles during antiviral PTI [8-12]; and (IV) virus encoded proteins that interact with host factors involved in PTI pathways and interfere with PTI-mediated signaling to activate effector-triggered susceptibility (ETS) [13-18].

On the other hand, to counteract ETS, plants have evolved intracellular resistance (R) proteins that directly or indirectly recognize pathogen effectors or Avr factors to activate ETI and trigger the second layer of defense. ETI is often manifested as a hypersensitive response (HR), characterized by rapid cell death, production of reactive oxygen species (ROS) and salicylic acid (SA) induction and expression of defense-related genes [19-21]. Since the first viral Avr factor and antiviral $R$ genes were identified in 1984 [22] and 1994 [23], increasingly diverse Avr factors and $\mathrm{R}$ proteins have been characterized in different virus-plant combinations. Most $\mathrm{R}$ proteins contain a nucleotide binding and leucine-rich repeat domain (NB-LRR) with an $\mathrm{N}$ terminal coiled coil domain (CC) or Toll/interleukin-1 receptors (TIR) domains. Increasing evidence also substantiates the notion that plants deploy typical ETI-based innate immune systems to control virus infections. The aim of this review is to summarize numerous advances about viral Avr factors and their roles in plant immunity.

\section{Coat Proteins (CP)}

The $\mathrm{CP}$, also known as the capsid protein, encapsidates and protects viral genomes from damage. Early expressed CPs function in disassembly of parental virions and have roles in assembly of progeny virions during the final infection steps. However, more and more evidence has shown that CPs of all plant viruses are multifunctional and have various roles during different replication stages, ranging from early to late events in the infection cycle. The diversity of these functions in different viral systems includes virus transmission by specific vectors, translation of viral RNA, regulation of intercellular and systemic movement of the virus, suppression of both post transcription gene silencing (PTGS) and transcription gene silencing (TGS), as well as determination of symptomatology and pathogenesis $[24,25]$. Owing to their obvious importance, $\mathrm{CPs}$ were the first example of pathogen-derived transgene resistance in plants [26]. In fact, CP encoded transgenic resistance provides an excellent solution to the global viral problems and provides an important venue for both basic and applied disease resistance breeding research and crop production [27].

Compared to CP-mediated genetic resistance engineered within the last 30 plus years, $\mathrm{CP}$-induced natural resistance has evolved over millions of years. The role of CPs in the activation of $R$ gene-mediated host defenses has been extensively characterized. The CPs of Tobacco mosaic virus (TMV), Tomato mosaic virus (ToMV), Tobacco mild green mosaic virus (TMGMV), Bell pepper mottle virus (BPeMV), Paprika mild mottle virus (PaMMV), Obuda pepper virus (ObPV), Pepper mild mottle virus (PMMoV), Potato virus X (PVX) and Mungbean yellow mosaic virus (MYMV) each serve as Avr factors that elicit resistance controlled by cognate dominant $R$ genes (Table 1 ).

TMV CP was identified as an Avr responsible for eliciting host ER responses during interactions with the Nicotiana sylvestris $N^{\prime}$ gene. Two groups independently found this property by analyzing a series of recombinant viruses between resistance-inducing (RI) and resistance-breaking (RB) strains [28-30]. Subsequently systematic studies of CP amino acid substitutions have demonstrated that $N^{\prime}$-mediated recognition requires maintenance of the $\mathrm{CP}$ three-dimensional structure, either directly, or through specific structural motifs [31,32]. The $N^{\prime}$ gene and its orthologues were recently cloned from N. sylvestris and other TMV resistant Nicotiana species and shown to encode CC-NB-LRR type proteins [33,34]. Interestingly, a more recent study of phylogeny of the $\mathrm{CP}$ of tombusviruses indicated that $\mathrm{CP}$ representatives of the family could be divided into four clades. All tested $\mathrm{CP}$ members in two separate clades triggered an HR in Nicotiana section Alatae species [35]. Moreover, a previous study had shown that several members of Nicotiana section Alatae carry functional 
$N^{\prime}$ orthologues [34] and implied that $N^{\prime}$ and $N^{\prime}$ orthologues might have been inherited from a common ancestor followed by evolution to confer tobamovirus and tombusvirus resistance to Nicotiana genus species. In pepper, a broadening spectrum of resistance to seven known pepper-infecting species of tobamoviruses (TMV, ToMV, TMGMV, BPeMV, PaMMV, $\mathrm{ObPV}$ and PMMoV) is conferred by the corresponding localization $(L)$ alleles [36]. $L$ gene alleles also encode CC-NB-LRR type resistance proteins with the ability to elicit resistance responses to different tobamoviral CP Avr effectors $[37,38]$. Since both $N^{\prime}$ and its Nicotiana orthologues and the $L$ alleles from pepper mediate resistance against tobamoviruses by recognizing the $\mathrm{CP}[33,34]$, it seems that these genes have evolved from a common Solanum ancestor. However, a resistance gene evolution assay indicates that the $L$ gene from pepper is not an $N^{\prime}$ orthologue, suggesting that tobamovirus resistances in pepper and Nicotiana originated independently [34]. Several $R$ genes within the same locus recognize different $\mathrm{CP}$ proteins from overlapping virus species indicating that the conserved $\mathrm{R}$ proteins are able to recognize similar structures but with an adapted spectrum. These results also support the idea that interactions between $L$ genes or $N^{\prime}$ orthologues and tobamovirus CPs serve as good systems for study the mechanisms and evolution of virus perception by plants.

Table 1. Plant virus avirulence (Avr) factor and cognate NB-LRR resistance genes.

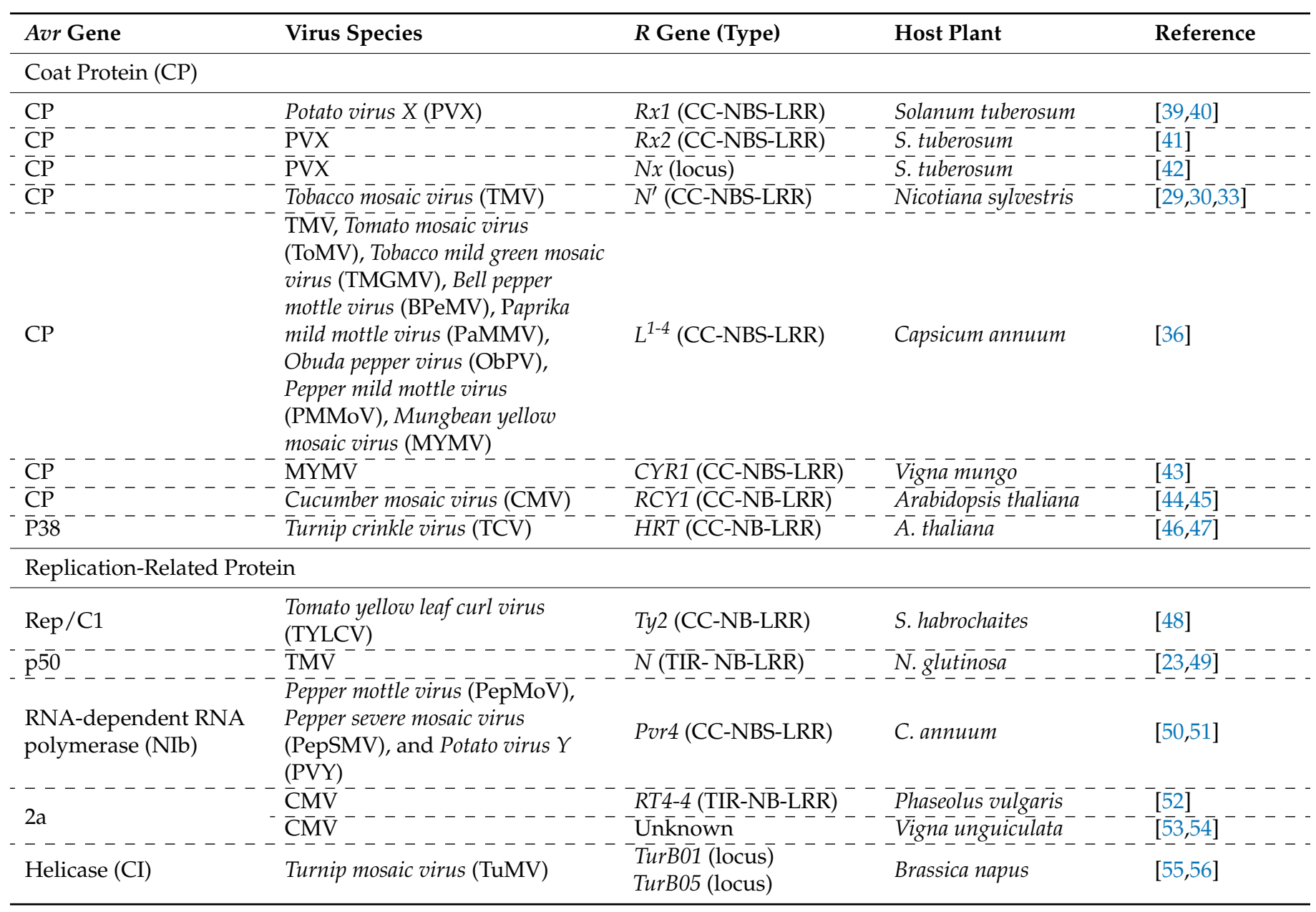


Table 1. Cont.

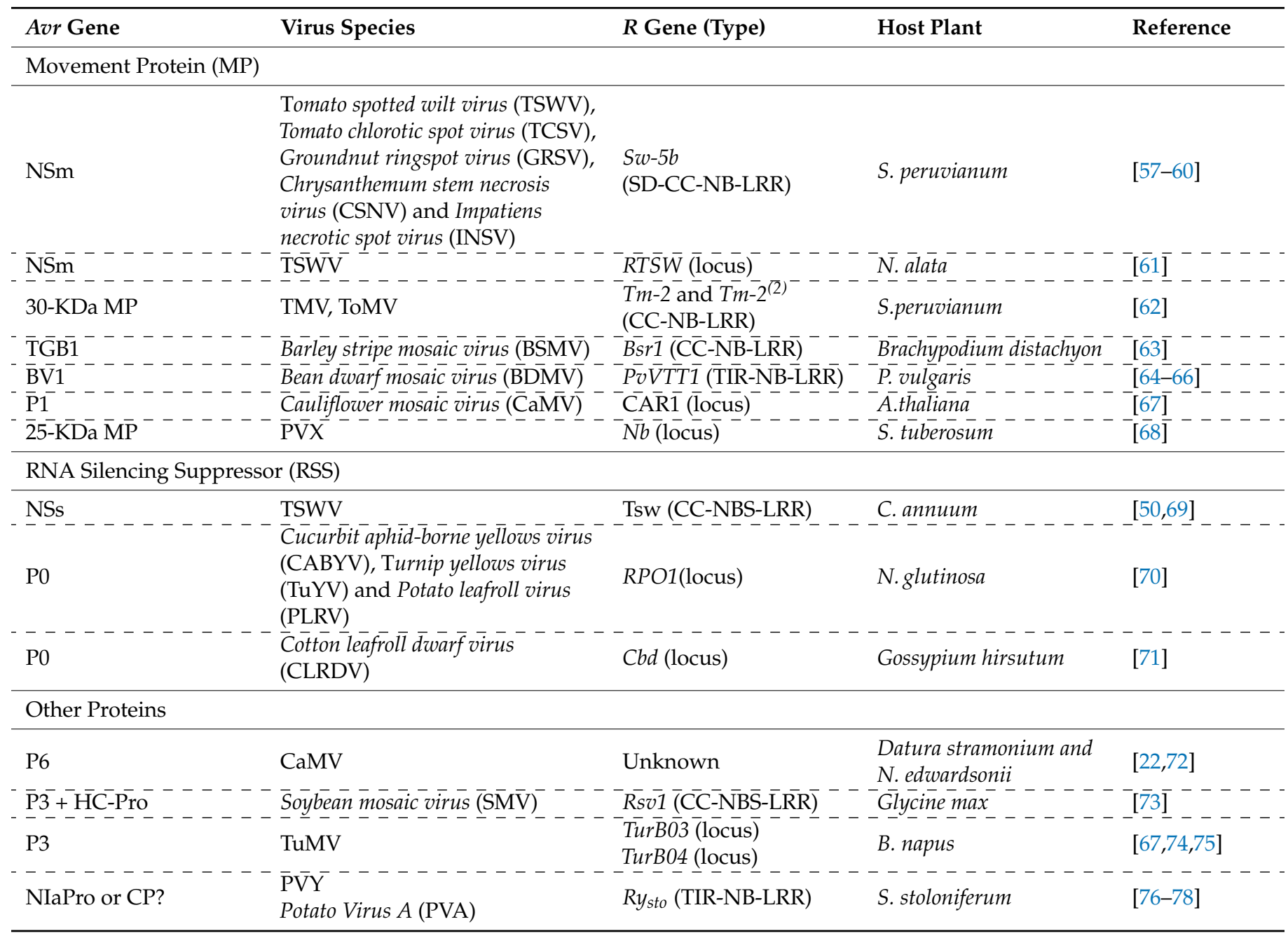

Another representative study involves PVX CP-elicited ER mediated by the Rx1 gene, which encodes a class of CC-NB-LRR R proteins in potato [39]. Under virus-free conditions, intramolecular interactions between the CC domain and NB or LRR domains retain $R \times 1$ in an auto-inhibited (off) state $[79,80]$. Upon PVX infection, Rx1 protein recognizes the PVX CP by leucine-rich repeat domain interactions that result in disruption of Rx1 intramolecular host interactions. However, PVX CP-induced ER by Rx1 does not involve natural cell death at the inoculation site, but instead suppresses virus replication per se, even in protoplast infections. In contrast, $R X 1$ does trigger an HR upon overexpression of the Avr PVX $\mathrm{CP}$ or under high PVX concentrations [40]. An additional study has demonstrated that nuclear-cytosolic shuttling of CP-activated Rx1 mediated by Ran GTPase-activating protein 2 (RanGAP2) is required for PVX defenses [81]. However, recent studies have shown that nuclear or cytosol restricted Rx1 variants cannot trigger ER or suppress the spread of virus infections, but can still induce an HR. Furthermore, perturbation of the nucleocytoplasmic distribution of $R x 1$ leads to translational arrest of PVX CP transcripts and compromises extreme resistance against PVX [82]. Thus, many mysteries still need to be addressed, e.g., how to explain the mutual regulation of the PVX CP and NLR activation and whether other important host factors are involved in ER and HR induction. Notably, another ER gene locus in potato, $N x$, also confers resistance to the PVX CP. However, ER by the Rx1 gene is induced via interactions with PVX CP conserved amino acids (aa) 121-127, whereas the Nx gene confers resistance to PVX through the recognition of PVX CP aa 62-78 [39,42,83]. 
In the Arabidopsis thaliana ecotype Di-17, Turnip crinkle virus (TCV) CP P38 functions as the Avr resistance determinant for the HRT CC-NB-LRR R protein [46,84]. By use of natural mutant isolates and interaction region screening, the TCV P38 $N$ terminus has been shown to be involved in eliciting resistance responses $[84,85]$. Moreover, the TCV P38 $N$ terminal nuclear localization domain is important for elicitation of host resistance responses and could be a key trigger for HRT-dependent resistance to TCV [86]. In another A. thaliana ecotype C24, RCY1, which encodes a CC-NB-LRR class R protein, was isolated and identified as the first $R$ gene conferring resistance to Cucumber mosaic virus (CMV) [44]. The CMV genes involved in the RCY1 Avr resistance response also mapped to the CP [45]. Interestingly, both the RCY1 and HRT R genes belong to HRT/RPP8 gene family, and the RCY1 locus in ecotype C24 were was found to be allelic to HRT in Dijon-17. These functionally divergence genes therefore seem to have evolved via recombination of ancestral genes [87]. More intriguingly, the CMV and TCV CPs, which lack sequence similarity, recognize the allelic RCY1 and HRT genes [45,84]. Therefore, several possibilities have been presented; one possibility is that RCY1 and HRT are elicited by completely different ligands. Another possibility is that the single CPs of CMV and TCV, or their possible complexes with other host components (e.g., guardee or decoy factor) may have highly similar CP protein folding domains [44].

\section{Replication-Related Proteins}

Replication of viruses in cells by use of their genetic information to commandeer host cell components and machinery is a major feature that distinguishes viruses from other pathogens. Plant DNA viruses, such as geminivirus, replicate by association with cellular DNA-dependent DNA polymerases in infected cell nuclei and formed minichromosomes [88]. In contrast, RNA replication results in rearrangements of intracellular membranes and frequently induces the formation of vesicles that contain RNA-dependent RNA polymerases and genomic RNA [89]. To replicate their genomes, viruses usurp host factors that interact with viral gene products via protein-protein or protein-nucleic acid interactions. One of the best studies using a yeast in vivo replication system has identified more than 250 host factors that interact with viral replicase, replication proteins, or the viral RNA to affect replication and recombination of TBSV [90]. In addition, large sets of data have demonstrated that both DNA and RNA virus replication-related proteins can elicit $R$ gene-driven effector triggered immunity (ETI) causing HR (Table 1).

$\mathrm{Ty}$-2 is a major source of dominant resistance against Tomato yellow leaf curl virus (TYLCV) that has been widely employed in tomato breeding programs that have released numerous commercial cultivars. Recently, Ty-2 was cloned and shown to encode a CCNB-LRR protein [48]. Using agroinfiltration to transiently co-express $T y$-2 along with the Rep/C1 and C4 genes of the RI and RB TYLCV strains, respectively, in N. benthamiana, only the RI TYLCV strain Rep/C1 protein consistently elicited a HR when co-expressed with the $\mathrm{Ty}$-2 protein. This result clearly indicates that the Rep/C1 protein is the Avr determinant triggering the $T y-2$ based (strain-specific) resistance response [48].

As the first and one of the best studied plant virus resistance genes, the $N$ gene was cloned almost twenty years ago and shown to be a member of the TIR-NBS-LRR class of plant disease resistance genes [23]. Subsequent efforts focused on identification of the viral Avr factor for the $N$ gene. Beachy's group initially reported a role for the 126/183-kDa replicase, but not the $\mathrm{CP}$ or $\mathrm{MP}$, in induction of $\mathrm{HR}$ in tobacco containing the $N$ gene [91], Later, they showed that the $126-\mathrm{kDa}$ protein sequence containing the methyltransferase and helicase-like domains, but not the 183-kDa readthrough protein containing the polymerase domain, is the Avr factor that triggers $N$-mediated defense responses [92]. Ultimately, Barbara Baker's team demonstrated that expression of the 50-kDa TMV helicase fragment (p50) of the 126-kDa replicase protein is sufficient to elicit $N$-mediated ER [49]. They also showed that HR induction depends on features of the p50 protein that are independent of its ATPase/helicase activity. Similar HR characteristics induced by avirulent replicases that are not dependent on the enzymatic activity of the protein also have been observed in the 
2a polymerase of CMV in cowpea plants [53]. The amino acid mutants that alter the highly conserved polymerase Gly-Asp-Asp (GDD) motif abolish replicase activity; however, these mutants do not affect HR induction in cowpea plants.

The Pvr4 gene encodes a broad-spectrum CC-NBS-LRR type resistance protein known to elicit resistance against multiple potyviruses, including Pepper mottle virus (PepMoV), Pepper severe mosaic virus (PepSMV) and Potato virus Y (PVY) in Capsicum annuum [50]. Kim et al. used agrobacterium transient expression of potyvirus coding regions and showed that the PepMoV, PepSMV and PVY RdRp NIbs proteins serve as Avr factors that elicit Pvr4 resistance in pepper plants [51]. The cylindrical inclusion (CI) protein of the potyvirus contains RNA helicase activities and are essential for genomic RNA replication. In the brassica-TuMV interaction system, the TuMV CI protein has been identified as the viral Avr determinant for two resistance genes, TuRB01 and TuRB05, in the AA subgenome of Brassica napus $[55,56]$.

\section{Movement Proteins (MP)}

Virus cell-to-cell and long distance movement throughout the plant from initial infection sites are controlled by specific viral MPs. Generally, plant virus movement is divided into three steps: (I) intracellular movement in which virus is trafficked along different organelles within a single cell from the sites of replication to the plasmodesmata [93]; (II) intercellular movement involving transport of virus through plasmodesmata (PD) cellwall structures serving as cytoplasmic connections between plant cells [94]; (III) systemic movement throughout the plant when viruses transit through the vascular system to distal leaves, roots and occasionally to reproductive organs $[95,96]$. Although different MPs have been shown to use various pathways and mechanisms for virus transport, numerous host factors and viral proteins may be required for each movement step.

Several examples have shown that viral MPs can elicit an HR response via interactions with $R$ gene products. One of the best-characterized systems is the interaction between the Tomato spotted wilt virus (TSWV) NSm movement protein with the tomato $S w-5 b$ and tobacco $R T S W$ resistance gene proteins. Sw- $5 \mathrm{~b}$ belongs to the CC-NB-LRR type immune receptors and contains an extended $\mathrm{N}$-terminal Solanaceae domain (SD) $[57,58]$. This $\mathrm{R}$ protein confers broad-spectrum resistance to various American-type orthotospoviruses but not to the Euro-Asian-type orthotospoviruses [57,97,98]. Two groups independently demonstrated at almost same time that $\mathrm{Sw}-5 \mathrm{~b}$ resistance is triggered by the NSm cellto-cell movement protein $[59,60]$. Subsequent work by Tao's group showed that a 21-aa peptide region positioned at aa $115-135$ in TSWV NSm $\left(\mathrm{NSm}^{21}\right)$, which is highly conserved among the American-type orthotospoviruses, but not the Euro-Asian-types, is sufficient to trigger Sw-5b-mediated HR $[97,99]$. In addition, the group also found that Sw-5b NLR adopts a two-step recognition mechanism to enhance NSm perception. In addition to direct interactions between the LRR domain and $\mathrm{NSm}$ or $\mathrm{NSm}^{21}$, the SD domain functions as an extra sensor to detect low levels of NSm or $\mathrm{NSm}^{21}$ and enhance resistance of Sw$5 \mathrm{~b}[100,101]$. RTSW, another $R$ locus from wild tobacco $N$. alata that confers ER to TSWV, has been introgressed into cultivated tobacco. By using two different transient expression systems, we showed that the NSm protein of TSWV acts as an Avr determinant of RTSWbased resistance [61]. Moreover, both our results and those of Tao's group showed that intercellular trafficking of NSm can be uncoupled from its HR function in the induction of RTSW and Sw-5b resistance [61,102]. More importantly, our evidence indicates that although $R T S W$ and $S w-5 b$ behave as single dominant genes that confer ER by interacting with the same NSm protein encoded by the same virus, they recognize different elicitor domains (EADs) [61]. The same pattern also has been shown to confer resistance to ToMV in tomato harboring the Tm-2 and Tm- $2^{(2)}$ genes. The 30-KDa MP of ToMV elicits both $T m-2$ and $T m-2^{(2)}$ resistance, but has different interacting domains [62] because the EADs map to the MP N- and C-termini, respectively [103].

The model grass Brachypodium distachyon Bd3-1 inbred line harbors a resistance gene designated Bsr1 that interacts with the Barley stripe mosaic virus (BSMV) ND18 triple gene 
block 1 (TGB1) movement protein to elicit ER during infection. Lee et al. have shown that two amino acids within the protein are required to elicit resistance, and that the BSMV Norwich strain has a two amino acid changes in TGB1 that abrogates necrosis to enable systemic infections [63]. In potatoes, the 25-kDa MP of PVX elicits Nb-Mediated ER, and that an isoleucine residue at position 6 of the MP protein is required for activation of the $\mathrm{Nb}$ response [68]. More intriguingly, recent evidence has revealed that the PVX MP functions as a silencing suppressor by directly targeting AGO1 degradation through the proteasome pathway [104]. Therefore, more systematic studies need to be conducted on this multifunctional protein to clarify the roles of important sites or domains in nucleotide binding, RNA helicase activity, plasmodesmatal gating, suppressor activity, etc.

\section{RNA Silencing Suppressors (RSS)}

RNA silencing (also known as RNA interference, RNAi) functions in endogenous gene regulatory and exogenous antiviral mechanisms in plants [105]. As a counterdefense, viruses have evolved RSS proteins that function to inhibit RNA silencing through diverse mechanisms [106,107]. The first mode of RSSs action is binding of long dsRNA or siRNA duplexes that arise during viral infections to inhibit siRNA biogenesis or RISC formation [108]. A second mode of action is binding to important components in the silencing pathway $[109,110]$. Recently, RNA silencing has been regarded as pattern-triggered immunity (PTI) against viruses and dsRNAs during the replication of RNA and DNA viruses and has been categorized as a pathogen-associated molecular patterns (PAMP) defense [111]. Consequently, by analogy of these steps in virus-host interactions with the steps outlined in the standard zigzag model, RSSs has been defined as a class of ETS that circumvents host RNA silencing and counters against the first layer of plant antiviral defenses [3,112,113]. Given the importance of suppressing RNA silencing for virus survival, it is not unexpected that direct and indirect interactions would occur between RSSs and $R$ genes to elicit ETI, which acts as a second plant defense layer [107].

The orthotospoviral NSs silencing suppressor protein is a well characterized RSS that conducts local and systemic silencing suppression functions by binding small and long dsRNAs [114,115]. Recently, NSs has been identified as the Avr determinant for Tswbased resistance in pepper [69]. Considering the role of NSs to counter defenses against RNA silencing, further dissections were tested by screening a large set of mutants for lost RI activity or silencing suppression. This result supports the idea that the NSs protein has evolved to fine tune and uncoupled Avr and RSS functions [116]. Recent studies tracing HR induction lineages and silencing suppression associated with the CPs of the Tombusviridae also support the conclusion that SSR and HR elicitation involve independent motifs. Among the four clades in the phylogenetic tree of 54 CPs tombusvirids, two separate CP clades triggered an HR in Nicotiana species of section Alatae but did not have silencing suppressor activity, whereas in one clade the CP functioned as an SSR, but lost the capacity to trigger HR in Nicotiana species [35].

The Polerovirus P0 protein is another well-known SSR that can mediate degradation of ARGONAUTE1 (AGO1), one of the most important components in RNA silencing and antiviral responses [117]. The N. glutinosa RPO1 gene elicits ER against poleroviruses Turnip yellows virus (TuYV) and Potato leafroll virus (PLRV), and is inherited as a single, dominant resistance allele. The P0 proteins from TuYV, PLRV and Cucurbit aphid-borne yellows virus (CABYV) were found to elicit an HR in N. glutinosa accessions containing the RPO1 locus. To dissect important roles of the P0 F-box motif in autophagic degradation of AGO1 proteins, motif mutants were constructed to test requirements for elicitation of RPO1mediated HR. The results showed that P0 mutants with substitutions in the F-box motif that abolished SSR activity were unable to elicit HR, suggesting that HR induction requires a functional P0 protein [70]. In cotton (Gossypium hirsutum), Cbd is a single dominant gene conferring ER to the polerovirus, cotton leafroll dwarf virus (CLDV). Agrofoglio and coworkers characterized the SSR activity of the P0 proteins encoded by wildtype (WT) CLRDV and a RB CLRDV isolate and evaluated the roles of these proteins in breaking 
Cbd-resistance in cotton plants. They found that WT and RB CLRDV P0s behave similarly during RNA silencing interference; however, RB CLRDV P0 enabled WT CLRDV and a chimeric infectious clone to systemically infect $C b d$-resistant cotton varieties. Therefore, the CLRDV P0 protein is also an Avr determinant that functions in Cbd-based resistance [71].

\section{Other Proteins}

In contrast to a simple classification in which ER caused by viral elicitors falls into the four categories above, research within the past few years shows that ER determinants are largely spread throughout the viral genome [118,119]. Additional elicitors of viral proteins, with the exception of those discussed in the previous sections, have been shown to contribute to viral ETI resistance. For example, the first plant virus avr gene, P6 of CaMV was identified through its capacity to elicit an HR in Datura stramonium and $N$. edwardsonii, by dissecting a series of gene swaps between infectious clones of different strains of CaMV [22,72]. Subsequent discreet studies further showed that P6 elicits a non-necrotic resistance response in N. glutinosa, but segregated independently from the cell death responses of $N$. edwardsonii or $N$. clevelandii $[120,121]$, although specific $R$ genes affecting these processes have not been isolated. P6 has also been recognized as a versatile viral protein that has key roles in several steps of virus infections [122]. For example, P6 is a transactivator of translation, a central component of amorphous inclusion bodies, an RSS and a main determinant of host range and pathogenicity [72,122-124]. P6 has also been associated with virus movement, modulates host defenses including both PTI and ETI, and suppresses SA-dependent autophagy [15,16,125-128]. Although the overall distinction between Avr triggering and other biology functions of P6 remain obscure, subtle assays have showed that the role of P6 in ER elicitation can be uncoupled from its roles as a translational transactivator $[129,130]$.

$\mathrm{Ry}_{\text {sto }}$ resistance, which confers ER against PVY and related viruses from the wild relative $S$. stoloniferum, has been widely employed in potato breeding programs as an importance resistance trait. Recently, the Rysto gene was cloned and found to encode a TIR-NB-LRR protein [76]. Nevertheless, the Avr determinant for Rysto was determined more than twenty years ago, when Mestre et al. demonstrated that the NIa proteinase

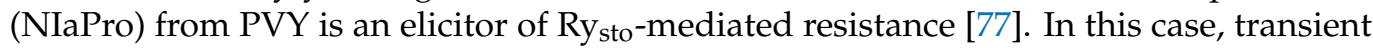
expression of PVY NIaPro by agro-infiltration elicited a HR in Rysto resistant but not in ry $_{\text {sto }}$ susceptible potato [77]. In a subsequent study, protease activity of NIaPro was shown to be required but not sufficient for elicitation of $R y_{s t o}$-mediated potyviral resistance [78]. However, conflicting results appeared after the Ry sto gene was isolated because similar transient expression strategies with different viral proteins from PVY and Potato virus $A$ (PVA) indicated that $\mathrm{Ry}_{\text {sto }}$ recognizes the CP but not other proteins as Avr factors in Rysto transgenic N. tabacum plants [76]. Therefore, it remains to be determined whether the HR phenotype is elicited by transient expression of different viral proteins (NIaPro and CP) or results from different interactions in the two experimental hosts (potato and tobacco).

In soybean plants (Glycine max), the Rsv1 gene confers resistance to the $\mathrm{N}$ strain of soybean mosaic virus (SMV), one of the most devastating potyviruses that causes huge economic losses in soybean production worldwide. Through construction of a series of chimeras and site-directed mutants, Eggenberger and colleagues mapped SMV P3 and helper-component proteinase (HC-Pro) components involved in elicitation of Rsv1mediated ER. Since P3 and HC-Pro are cistrons within a read-through protein, it seems that HC-Pro and P3 are recognized by Rsv1-mediated defense responses as a precursor polyprotein [73]. More recent research revealed that the complexity of the Rsv1 locus may be a reason why the recognition sites are distributed throughout the HC-Pro and P3 cistrons. Multiple distinct resistance genes, likely belonging to the NB-LRR class, have been discovered within the Rsv1 locus [131]. In addition, the P3 protein alone was found to be an Avr determinant for two dominant resistance genes, TuRBO3 and TuRB04, in the brassica-TuMV interaction system $[56,74]$. 


\section{Application of Viral Avr Factors in Resistance Studies}

7.1. Agrobacterium Co-Infiltration Transient Expression as a Tool for Isolation and Identification of Disease Resistance Genes

In early studies, viral Avr factor identification was conducted via several approaches including gene swaps between resistance and susceptible virus strains or mutants, and ectopic expression of Avr candidate genes within a virus vector. Subsequently, agroinfiltration has been shown to be a more convenient and powerful tool for screening of viral proteins capable of triggering HR in R-containing plant hosts. According to the 'gene-for-gene' theory, one $R$ gene product in the plant specifically perceives a matching effector protein, and a definitive Avr gene also can be inversely employed to screen for corresponding $R$ genes. Several successful case studies have demonstrated the utility and operability of this approach [41,132]. In contrast to Avr factor screening, in which single Avr candidate genes are agroinfiltrated into resistance host plants, $R$ gene screening is conducted by mixing agrobacterium strains carrying the candidate $R$ gene and the Avr genes, and the mixtures are co-infiltrated into susceptible host plants such as N. benthamiana. Compared to the several months required for transgenic assays or gene knockout assays, agrobacterium co-infiltration transient expression systems just require two or three days. Previous experiments have confirmed that $R \times 2$ (AC15 clone) and RP28 genes can be easily and quickly isolated from a $200 \mathrm{Rx}$ homologue library from potato and a 99 candidate $R$ gene library from pepper by using Agrobacterium coinfiltration approaches [41,132]. Therefore, the Agrobacterium approach is a handy tool that is less time consuming and labor intensive than the more traditional methods. The Agrobacterium system could also provide a convenient method to identify disease resistance genes because $R$ genes encoding NB-LRR type receptors are frequently members of large gene families, organized in complex clusters of paralogous genes in the plant genome. Of course, several additional candidate R homologues still may need to be cloned and identified even if located within a very narrow chromosome fine mapping region.

\subsection{Avr Gene-Based Diagnostic Approaches for Allele Identification and Phenotyping}

Identification of new candidates for virus resistance is a prerequisite for effective utilization of diverse germplasm in breeding programs. Multiple alleles arising by rapid evolution through tandem and segmental gene duplications, recombination, unequal crossing-over or point mutations are common within $R$ gene families. The high sequence similarity of encoding and flanking regions of $R$ gene alleles by marker assisted genotyping are huge challenges. However, coevolution and diversified selection of $R$ genes and the pathogen's Avr effectors often result in multiple recognition regions between a single $R$ gene with each allele and corresponding species or strain-specific Avrs. Several examples of allelic series of virus $R$ genes are known in plants; for example the $L^{1}, L^{2}, L^{3}$, and $L^{4}$ alleles confer broad spectrum of resistance to different tobamoviruses by recognizing their $\mathrm{CP}$ elicitors [36]. Therefore, HR phenotyping by using specific recognition between $\mathrm{R}$ and Avr proteins represents an alternative approach to screen different alleles from germplasm variants. In this regard, Avr gene-based phenotyping has been established and applied to rice blast disease resistance identification in the field by using different Avr factors [133].

For fine mapping and cloning of virus resistance genes, a precise disease resistance test is a prime requirement for resistance identification in segregation populations, e.g., F2, BC, RIL or NIL populations. Traditional virus disease resistance tests performed in mapping or breeding programs involves virus infectious clones, insect vectors, or sap mediated virus inoculations. However, the obvious shortcomings of these methods, including low accuracy, complicated operations, time consuming experiments, and labor intensive trials has limited their wide application. However, our experience has indicated that Avr genebased diagnostic approaches can provide rapid disease resistance tests that overcome limitations of virus sap inoculations and greatly improve the efficiency and accuracy of test plant inoculations [61]. 


\section{Conclusions and Perspectives}

Over the past three decades, our knowledge about plant virus resistance genes and corresponding Avr factors has advanced dramatically. Compared to other pathogens (i.e., bacterial, fungal and oomycetes), viral Avr gene identification is relatively easy due to small virus genome sizes and limited numbers of gene products. Most virus Avr genes have been matched with an $R$-gene type NB-LRR receptor (Table 1). However, Avr genes that elicit activity of some mapped or cloned antiviral $R$ genes have not yet been identified. These include the I gene in Phaseolus vulgaris that confers resistance to multiple potyviruses [134], $Y-1$ in S. tuberosum resistance to PVY [135], Pv1 and Pv2 in Cucumis melo resistance to Papaya ringspot virus [136], Ctv resistance in Poncirus trifoliate to Citrus tristeza virus [137] and BcTuR03 resistance in B. campestris to TuMV [138]. Thus, further studies need to be conducted to identify Avr factors and their roles in eliciting resistance and functions in virus multiplication.

Previous studies with virus Avr-R interactions have provided new insights and paved the way to plant innate immunity studies of other pathogens. Among these are investigations of direct interactions between $\mathrm{NSm}\left(\right.$ or NSm ${ }^{21}$ ) and $\mathrm{Sw}-5 \mathrm{~b}$ that revealed a novel two-step recognition mechanism involving the SD and LRR domains of Sw-5b $[97,100]$, indirect interactions between the $N$ gene and TMV p50 mediated by an intermediate protein NRIP1 [139] and recognition of the TMV MP by Tm- $2^{(2)}$ involving an intermediate NbMIP1 $[140,141]$. These results indicate that associations between NLRs and their corresponding effectors may not be sufficient to directly activate R protein defense responses, but may require additional molecular partners. In contrast to the well characterizations of TSWV Nsm/Sw-5b, TMV p50/N, PVX CP/Rx1, ToMV MP/Tm- $2^{(2)}$, other Avr and R proteins interactions were limitedly characterized experimentally. Thus, a major challenge for the future is to identify the precise interaction mechanisms between viral Avr factors and their matching NB-LRR type receptors, as it is possible such multi host interactions are common. The resolution of such mechanisms may require more powerful technological tools to detect and analyze subtle signaling complexes. Nevertheless, several novel experimental approaches, including TurboID-based proximity labeling, high throughput omics analyses, protein-protein interaction networks and machine learning technologies have recently demonstrated their potential for comprehensive understanding of complex biological process such as Avr/R protein signaling cascades [142,143].

Notably, recent cryo-EM structural and functional analyses of CC-NB-LRR (ZAR1) and TIR-NB-LRR (ROQ1 and RPP1) proteins have shed new light on resistosome signaling mechanisms and provide an excellent template for other CC- and TIR-NB-LRR protein functional cascades [144-147]. It would be interesting to discover whether other CC-NB-LRR proteins self-associate and oligomerize into larger structures to form membrane pores since previous results have revealed distinct subcellular localization of $\mathrm{R}$ proteins. For instance, nucleocytoplasmic shuttling requirements of the PVX CP activated Rx1[81], Tm-2 ${ }^{(2)}$ functions on the plasma membrane [140] and Sw-5b exhibits nucleocytoplasmic localization patterns in the absence of virus infections or NSm induction $[139,148]$. It also would be worthwhile to determine whether other TIR-NB-LRR proteins form tetrameric assemblies that act as holoenzymes to mediate $\mathrm{NAD}^{+}$hydrolysis that can trigger plant immunity responses. Future steps will require advances in structural studies, understanding patterns and mechanisms of $\mathrm{R}$ protein recognition and activation of viral Avr factors. Addressing such fundamental mechanisms will clarify major gaps in our understanding of plant virus defense networks.

Funding: This study was funded by the Key program of YNTC (2018530000241004), National Natural Science Foundation of China (No. 31960530 and 31460462), and Project for Technological Innovation Talents of Yunnan (2017HB093) and High-Level Talent Cultivation Support Plan of Yunnan Province (YNWR-QNBJ-2018-079). 
Acknowledgments: The author thanks Andrew Jackson from UC Berkeley for constructive criticism and suggestions to the manuscript. The author also appreciates the anonymous reviewers for their helpful comments and suggestions to this paper.

Conflicts of Interest: The authors declare no conflict of interest.

\section{References}

1. Jones, J.D.; Dangl, J.L. The plant immune system. Nature 2006, 444, 323-329. [CrossRef] [PubMed]

2. Niehl, A.; Wyrsch, I.; Boller, T.; Heinlein, M. Double-stranded RNAs induce a pattern-triggered immune signaling pathway in plants. New Phytol. 2016, 211, 1008-1019. [CrossRef] [PubMed]

3. Amari, K.; Niehl, A. Nucleic acid-mediated PAMP-triggered immunity in plants. Curr. Opin. Virol. 2020, 42, 32-39. [CrossRef] [PubMed]

4. Koziel, E.; Otulak-Koziel, K.; Bujarski, J.J. Plant Cell Wall as a Key Player During Resistant and Susceptible Plant-Virus Interactions. Front. Microbiol. 2021, 12, 656809. [CrossRef] [PubMed]

5. Otulak-Koziel, K.; Koziel, E.; Lockhart, B.E.L. Plant Cell Wall Dynamics in Compatible and Incompatible Potato Response to Infection Caused by Potato Virus Y (PVY(NTN)). Int. J. Mol. Sci. 2018, 19, 862. [CrossRef]

6. Otulak-Koziel, K.; Koziel, E.; Bujarski, J.J. Spatiotemporal Changes in Xylan-1/Xyloglucan and Xyloglucan Xyloglucosyl Transferase (XTH-Xet5) as a Step-In of Ultrastructural Cell Wall Remodelling in Potato(-)Potato Virus Y (PVY(NTN)) Hypersensitive and Susceptible Reaction. Int. J. Mol. Sci. 2018, 19, 2287. [CrossRef]

7. Otulak-Koziel, K.; Koziel, E.; Lockhart, B.E.L.; Bujarski, J.J. The Expression of Potato Expansin A3 (StEXPA3) and Extensin4 (StEXT4) Genes with Distribution of StEXPAs and HRGPs-Extensin Changes as an Effect of Cell Wall Rebuilding in Two Types of PVY(NTN)-Solanum tuberosum Interactions. Viruses 2020, 12, 66. [CrossRef]

8. Guzman-Benito, I.; Donaire, L.; Amorim-Silva, V.; Vallarino, J.G.; Esteban, A.; Wierzbicki, A.T.; Ruiz-Ferrer, V.; Llave, C. The immune repressor BIR1 contributes to antiviral defense and undergoes transcriptional and post-transcriptional regulation during viral infections. New Phytol. 2019, 224, 421-438. [CrossRef]

9. Korner, C.J.; Klauser, D.; Niehl, A.; Dominguez-Ferreras, A.; Chinchilla, D.; Boller, T.; Heinlein, M.; Hann, D.R. The immunity regulator BAK1 contributes to resistance against diverse RNA viruses. Mol. Plant Microbe Interact. 2013, 26, 1271-1280. [CrossRef]

10. Teixeira, R.M.; Ferreira, M.A.; Raimundo, G.A.S.; Loriato, V.A.P.; Reis, P.A.B.; Fontes, E.P.B. Virus perception at the cell surface: Revisiting the roles of receptor-like kinases as viral pattern recognition receptors. Mol. Plant Pathol. 2019, 20, 1196-1202. [CrossRef]

11. Yang, H.; Gou, X.; He, K.; Xi, D.; Du, J.; Lin, H.; Li, J. BAK1 and BKK1 in Arabidopsis thaliana confer reduced susceptibility to turnip crinkle virus. Eur. J. Plant Pathol. 2010, 127, 149-156. [CrossRef]

12. Zorzatto, C.; Machado, J.P.B.; Lopes, K.V.G.; Nascimento, K.J.T.; Pereira, W.A.; Brustolini, O.J.B.; Reis, P.A.B.; Calil, I.P.; Deguchi, M.; Sachetto-Martins, G.; et al. NIK1-mediated translation suppression functions as a plant antiviral immunity mechanism. Nature 2015, 520, 679-682. [CrossRef]

13. Garnelo Gómez, B.; Zhang, D.; Rosas-Díaz, T.; Wei, Y.; Macho, A.P.; Lozano-Durán, R. The C4 protein from Tomato yellow leaf curl virus can broadly interact with plant receptor-like kinases. Viruses 2019, 11, 1009. [CrossRef]

14. Hu, T.; Huang, C.; He, Y.; Castillo-Gonzalez, C.; Gui, X.; Wang, Y.; Zhang, X.; Zhou, X. betaC1 protein encoded in geminivirus satellite concertedly targets MKK2 and MPK4 to counter host defense. PLoS Pathog. 2019, 15, e1007728. [CrossRef]

15. Geri, C.; Love, A.J.; Cecchini, E.; Barrett, S.J.; Laird, J.; Covey, S.N.; Milner, J.J. Arabidopsis mutants that suppress the phenotype induced by transgene-mediated expression of cauliflower mosaic virus (CaMV) gene VI are less susceptible to CaMV-infection and show reduced ethylene sensitivity. Plant Mol. Biol. 2004, 56, 111-124. [CrossRef]

16. Love, A.J.; Geri, C.; Laird, J.; Carr, C.; Yun, B.W.; Loake, G.J.; Tada, Y.; Sadanandom, A.; Milner, J.J. Cauliflower mosaic virus protein P6 inhibits signaling responses to salicylic acid and regulates innate immunity. PLoS ONE 2012, 7, e47535. [CrossRef]

17. Nicaise, V.; Candresse, T. Plum pox virus capsid protein suppresses plant pathogen-associated molecular pattern (PAMP)-triggered immunity. Mol. Plant Pathol. 2017, 18, 878-886. [CrossRef]

18. Kong, J.; Wei, M.; Li, G.; Lei, R.; Qiu, Y.; Wang, C.; Li, Z.H.; Zhu, S. The cucumber mosaic virus movement protein suppresses PAMP-triggered immune responses in Arabidopsis and tobacco. Biochem. Biophys. Res. Commun. 2018, 498, 395-401. [CrossRef]

19. Mandadi, K.K.; Scholthof, K.B. Plant immune responses against viruses: How does a virus cause disease? Plant Cell 2013, 25, 1489-1505. [CrossRef]

20. De Ronde, D.; Butterbach, P.; Kormelink, R. Dominant resistance against plant viruses. Front. Plant Sci. 2014, 5, 307. [CrossRef]

21. Meier, N.; Hatch, C.; Nagalakshmi, U.; Dinesh-Kumar, S.P. Perspectives on intracellular perception of plant viruses. Mol. Plant Pathol. 2019, 20, 1185-1190. [CrossRef] [PubMed]

22. Daubert, S.D.; Schoelz, J.; Debao, L.; Shepherd, R.J. Expression of disease symptoms in cauliflower mosaic virus genomic hybrids. J. Mol. Appl. Genet. 1984, 2, 537-547. [PubMed]

23. Whitham, S.; Dinesh-Kumar, S.P.; Choi, D.; Hehl, R.; Corr, C.; Baker, B. The product of the Tobacco mosaic virus resistance gene N: Similarity to toll and the interleukin-1 receptor. Cell 1994, 78, 1101-1115. [CrossRef]

24. Wang, A. Dissecting the molecular network of virus-plant interactions: The complex roles of host factors. Annu. Rev. Phytopathol. 2015, 53, 45-66. [CrossRef] [PubMed]

25. Bol, J.F. Role of Capsid Proteins. In Plant Virology Protocols: From Viral Sequence to Protein Function; Foster, G.D., Johansen, I.E., Hong, Y., Nagy, P.D., Eds.; Humana Press: Totowa, NJ, USA, 2008; pp. 21-31. 
26. Abel, P.P.; Nelson, R.S.; De, B.; Hoffmann, N.; Rogers, S.G.; Fraley, R.T.; Beachy, R.N. Delay of disease development in transgenic plants that express the Tobacco mosaic virus coat protein gene. Science 1986, 232, 738-743. [CrossRef]

27. Lindbo, J.A.; Falk, B.W. The Impact of "Coat Protein-Mediated Virus Resistance” in Applied Plant Pathology and Basic Research. Phytopathology 2017, 107, 624-634. [CrossRef]

28. Knorr, D.A.; Dawson, W.O. A point mutation in the Tobacco mosaic virus capsid protein gene induces hypersensitivity in Nicotiana sylvestris. Proc. Natl. Acad. Sci. USA 1988, 85, 170-174. [CrossRef]

29. Culver, J.N.; Dawson, W.O. Tobacco mosaic virus coat protein: An elicitor of the hypersensitive reaction but not required for the development of mosaic symptoms in Nicotiana sylvestris. Virology 1989, 173, 755-758. [CrossRef]

30. Saito, T.; Meshi, T.; Takamatsu, N.; Okada, Y. Coat protein gene sequence of tobacco mosaic virus encodes a host response determinant. Proc. Natl. Acad. Sci. USA 1987, 84, 6074-6077. [CrossRef]

31. Culver, J.N.; Stubbs, G.; Dawson, W.O. Structure-function relationship between tobacco mosaic virus coat protein and hypersensitivity in Nicotiana sylvestris. J. Mol. Biol. 1994, 242, 130-138. [CrossRef]

32. Culver, J.N. Tobacco mosaic virus assembly and disassembly: Determinants in pathogenicity and resistance. Annu. Rev. Phytopathol. 2002, 40, 287-308. [CrossRef]

33. Sekine, K.T.; Tomita, R.; Takeuchi, S.; Atsumi, G.; Saitoh, H.; Mizumoto, H.; Kiba, A.; Yamaoka, N.; Nishiguchi, M.; Hikichi, Y.; et al. Functional differentiation in the leucine-rich repeat domains of closely related plant virus-resistance proteins that recognize common avr proteins. Mol. Plant Microbe Interact. 2012, 25, 1219-1229. [CrossRef]

34. Yuan, X.; Yan, C.; Wu, Z.; Ren, F.; Zhang, H.; Baker, B.; Chen, J.; Kuang, H. Frequent Gain and Loss of Resistance against Tobacco Mosaic Virus in Nicotiana Species. Mol. Plant 2015, 8, 1813-1815. [CrossRef]

35. Adhab, M.; Angel, C.; Rodriguez, A.; Fereidouni, M.; Kiraly, L.; Scheets, K.; Schoelz, J.E. Tracing the Lineage of Two Traits Associated with the Coat Protein of the Tombusviridae: Silencing Suppression and HR Elicitation in Nicotiana Species. Viruses 2019, 11, 588. [CrossRef]

36. Tomita, R.; Sekine, K.T.; Mizumoto, H.; Sakamoto, M.; Murai, J.; Kiba, A.; Hikichi, Y.; Suzuki, K.; Kobayashi, K. Genetic basis for the hierarchical interaction between Tobamovirus spp. and $L$ resistance gene alleles from different pepper species. Mol. Plant Microbe Interact. 2011, 24, 108-117. [CrossRef]

37. Berzal-Herranz, A.; de la Cruz, A.; Tenllado, F.; Diaz-Ruiz, J.R.; Lopez, L.; Sanz, A.I.; Vaquero, C.; Serra, M.T.; Garcia-Luque, I. The Capsicum $L^{3}$ gene-mediated resistance against the tobamoviruses is elicited by the coat protein. Virology 1995, 209, 498-505. [CrossRef]

38. De la Cruz, A.; Lopez, L.; Tenllado, F.; Diaz-Ruiz, J.R.; Sanz, A.I.; Vaquero, C.; Serra, M.T.; Garcia-Luque, I. The coat protein is required for the elicitation of the Capsicum $L^{2}$ gene-mediated resistance against the tobamoviruses. Mol. Plant Microbe Interact. 1997, 10, 107-113. [CrossRef]

39. Bendahmane, A.; Kohn, B.A.; Dedi, C.; Baulcombe, D.C. The coat protein of Potato virus X is a strain-specific elicitor of Rx1mediated virus resistance in potato. Plant J. 1995, 8, 933-941. [CrossRef]

40. Bendahmane, A.; Kanyuka, K.; Baulcombe, D.C. The Rx gene from potato controls separate virus resistance and cell death responses. Plant Cell 1999, 11, 781-792. [CrossRef]

41. Bendahmane, A.; Querci, M.; Kanyuka, K.; Baulcombe, D.C. Agrobacterium transient expression system as a tool for the isolation of disease resistance genes: Application to the Rx2 locus in potato. Plant J. 2000, 21, 73-81. [CrossRef]

42. Cruz, S.S.; Baulcombe, D.C. Molecular analysis of Potato virus X isolates in relation to the potato hypersensitivity gene Nx. Mol. Plant Microbe Interact. 1993, 6, 707-714. [CrossRef]

43. Maiti, S.; Paul, S.; Pal, A. Isolation, characterization, and structure analysis of a non-TIR-NBS-LRR encoding candidate gene from MYMIV-resistant Vigna mungo. Mol. Biotechnol. 2012, 52, 217-233. [CrossRef]

44. Takahashi, H.; Miller, J.; Nozaki, Y.; Takeda, M.; Shah, J.; Hase, S.; Ikegami, M.; Ehara, Y.; Dinesh-Kumar, S.P.; Sukamto. RCY1, an Arabidopsis thaliana RPP8/HRT family resistance gene, conferring resistance to cucumber mosaic virus requires salicylic acid, ethylene and a novel signal transduction mechanism. Plant J. 2002, 32, 655-667. [CrossRef]

45. Takahashi, H.; Suzuki, M.; Natsuaki, K.; Shigyo, T.; Hino, K.; Teraoka, T.; Hosokawa, D.; Ehara, Y. Mapping the virus and host genes involved in the resistance response in cucumber mosaic virus-Infected Arabidopsis thaliana. Plant Cell Physiol. 2001, 42, 340-347. [CrossRef]

46. Ren, T.; Qu, F.; Morris, T.J. HRT gene function requires interaction between a NAC protein and viral capsid protein to confer resistance to turnip crinkle virus. Plant Cell 2000, 12, 1917-1926. [CrossRef]

47. Cooley, M.B.; Pathirana, S.; Wu, H.J.; Kachroo, P.; Klessig, D.F. Members of the Arabidopsis HRT / RPP8 family of resistance genes confer resistance to both viral and oomycete pathogens. Plant Cell 2000, 12, 663-676. [CrossRef]

48. Shen, X.; Yan, Z.; Wang, X.; Wang, Y.; Arens, M.; Du, Y.; Visser, R.G.F.; Kormelink, R.; Bai, Y.; Wolters, A.A. The NLR Protein Encoded by the Resistance Gene Ty-2 Is Triggered by the Replication-Associated Protein Rep/C1 of Tomato Yellow Leaf Curl Virus. Front. Plant Sci. 2020, 11, 545306. [CrossRef]

49. Erickson, F.L.; Holzberg, S.; Calderon-Urrea, A.; Handley, V.; Axtell, M.; Corr, C.; Baker, B. The helicase domain of the TMV replicase proteins induces the $N$-mediated defence response in tobacco. Plant J. 1999, 18, 67-75. [CrossRef]

50. Kim, S.B.; Kang, W.H.; Huy, H.N.; Yeom, S.I.; An, J.T.; Kim, S.; Kang, M.Y.; Kim, H.J.; Jo, Y.D.; Ha, Y.; et al. Divergent evolution of multiple virus-resistance genes from a progenitor in Capsicum spp. New Phytol. 2017, 213, 886-899. [CrossRef] 
51. Kim, S.B.; Lee, H.Y.; Seo, S.; Lee, J.H.; Choi, D. RNA-dependent RNA polymerase (NIb) of the potyviruses is an avirulence factor for the broad-spectrum resistance gene Pvr4 in Capsicum annuum cv. CM334. PLoS ONE 2015, 10, e0119639. [CrossRef]

52. Seo, Y.S.; Rojas, M.R.; Lee, J.Y.; Lee, S.W.; Jeon, J.S.; Ronald, P.; Lucas, W.J.; Gilbertson, R.L. A viral resistance gene from common bean functions across plant families and is up-regulated in a non-virus-specific manner. Proc. Natl. Acad. Sci. USA 2006, 103, 11856-11861. [CrossRef] [PubMed]

53. Hu, Z.; Zhang, T.; Yao, M.; Feng, Z.; Miriam, K.; Wu, J.; Zhou, X.; Tao, X. The 2a protein of Cucumber mosaic virus induces a hypersensitive response in cowpea independently of its replicase activity. Virus Res. 2012, 170, 169-173. [CrossRef] [PubMed]

54. Kim, C.H.; Palukaitis, P. The plant defense response to cucumber mosaic virus in cowpea is elicited by the viral polymerase gene and affects virus accumulation in single cells. EMBO J. 1997, 16, 4060-4068. [CrossRef] [PubMed]

55. Jenner, C.E.; Sanchez, F.; Nettleship, S.B.; Foster, G.D.; Ponz, F.; Walsh, J.A. The cylindrical inclusion gene of Turnip mosaic virus encodes a pathogenic determinant to the Brassica resistance gene TuRB01. Mol. Plant Microbe Interact. 2000, 13, 1102-1108. [CrossRef]

56. Jenner, C.E.; Tomimura, K.; Ohshima, K.; Hughes, S.L.; Walsh, J.A. Mutations in Turnip mosaic virus P3 and cylindrical inclusion proteins are separately required to overcome two Brassica napus resistance genes. Virology 2002, 300, 50-59. [CrossRef]

57. Brommonschenkel, S.H.; Frary, A.; Frary, A.; Tanksley, S.D. The broad-spectrum tospoVirus Res.istance gene $S w-5$ of tomato is a homolog of the root-knot nematode resistance gene Mi. Mol. Plant Microbe Interact. 2000, 13, 1130-1138. [CrossRef]

58. Spassova, M.; Prins, T.; Folkertsma, R.; Klein-Lankhorst, R.; Hille, J.; Goldbach, R.; Prins, M. The tomato gene Sw5 is a member of the coiled coil, nucleotide binding, leucine-rich repeat class of plant resistance genes and confers resistance to TSWV in tobacco. Mol. Breed. 2001, 7, 151-161. [CrossRef]

59. Hallwass, M.; de Oliveira, A.S.; de Campos Dianese, E.; Lohuis, D.; Boiteux, L.S.; Inoue-Nagata, A.K.; Resende, R.O.; Kormelink, $\mathrm{R}$. The Tomato spotted wilt virus cell-to-cell movement protein (NSM) triggers a hypersensitive response in Sw-5-containing resistant tomato lines and in Nicotiana benthamiana transformed with the functional Sw-5b resistance gene copy. Mol. Plant Pathol. 2014, 15, 871-880. [CrossRef]

60. Peiro, A.; Canizares, M.C.; Rubio, L.; Lopez, C.; Moriones, E.; Aramburu, J.; Sanchez-Navarro, J. The movement protein (NSm) of Tomato spotted wilt virus is the avirulence determinant in the tomato Sw-5 gene-based resistance. Mol. Plant Pathol. 2014, 15, 802-813. [CrossRef]

61. Huang, C.; Liu, Y.; Yu, H.; Yuan, C.; Zeng, J.; Zhao, L.; Tong, Z.; Tao, X. Non-Structural Protein NSm of Tomato Spotted Wilt Virus Is an Avirulence Factor Recognized by Resistance Genes of Tobacco and Tomato via Different Elicitor Active Sites. Viruses 2018, 10, 660. [CrossRef]

62. Lanfermeijer, F.C.; Dijkhuis, J.; Sturre, M.J.; de Haan, P.; Hille, J. Cloning and characterization of the durable tomato mosaic Virus Res.istance gene Tm-2 ${ }^{(2)}$ from Lycopersicon esculentum. Plant Mol. Biol. 2003, 52, 1037-1049. [CrossRef]

63. Lee, M.Y.; Yan, L.; Gorter, F.A.; Kim, B.Y.T.; Cui, Y.; Hu, Y.; Yuan, C.; Grindheim, J.; Ganesan, U.; Liu, Z.; et al. Brachypodium distachyon line Bd3-1 resistance is elicited by the barley stripe mosaic virus triple gene block 1 movement protein. J. Gen. Virol. 2012, 93, 2729-2739. [CrossRef]

64. Seo, Y.S.; Jeon, J.S.; Rojas, M.R.; Gilbertson, R.L. Characterization of a novel Toll/interleukin-1 receptor (TIR)-TIR gene differentially expressed in common bean (Phaseolus vulgaris cv. Othello) undergoing a defence response to the geminivirus Bean dwarf mosaic virus. Mol. Plant Pathol. 2007, 8, 151-162. [CrossRef]

65. Garrido-Ramirez, E.R.; Sudarshana, M.R.; Lucas, W.J.; Gilbertson, R.L. Bean dwarf mosaic virus BV1 protein is a determinant of the hypersensitive response and avirulence in Phaseolus vulgaris. Mol. Plant Microbe Interact. 2000, 13, 1184-1194. [CrossRef]

66. Zhou, Y.C.; Garrido-Ramirez, E.R.; Sudarshana, M.R.; Yendluri, S.; Gilbertson, R.L. The N-terminus of the Begomovirus nuclear shuttle protein (BV1) determines virulence or avirulence in Phaseolus vulgaris. Mol. Plant Microbe Interact. 2007, 20, 1523-1534. [CrossRef]

67. Adhab, M.; Angel, C.; Leisner, S.; Schoelz, J.E. The P1 gene of Cauliflower mosaic virus is responsible for breaking resistance in Arabidopsis thaliana ecotype Enkheim (En-2). Virology 2018, 523, 15-21. [CrossRef]

68. Malcuit, I.; Marano, M.R.; Kavanagh, T.A.; De Jong, W.; Forsyth, A.; Baulcombe, D.C. The 25-kDa Movement Protein of PVX Elicits Nb-Mediated Hypersensitive Cell Death in Potato. Mol. Plant Microbe Interact. 1999, 12, 536-543. [CrossRef]

69. De Ronde, D.; Butterbach, P.; Lohuis, D.; Hedil, M.; van Lent, J.W.; Kormelink, R. Tsw gene-based resistance is triggered by a functional RNA silencing suppressor protein of the Tomato spotted wilt virus. Mol. Plant Pathol. 2013, 14, 405-415. [CrossRef]

70. Wang, K.D.; Empleo, R.; Nguyen, T.T.; Moffett, P.; Sacco, M.A. Elicitation of hypersensitive responses in Nicotiana glutinosa by the suppressor of RNA silencing protein P0 from poleroviruses. Mol. Plant Pathol. 2015, 16, 435-448. [CrossRef]

71. Agrofoglio, Y.C.; Delfosse, V.C.; Casse, M.F.; Hopp, H.E.; Bonacic Kresic, I.; Ziegler-Graff, V.; Distéfano, A.J. P0 protein of cotton leafroll dwarf virus-atypical isolate is a weak RNA silencing suppressor and the avirulence determinant that breaks the cotton $C b d$ gene-based resistance. Plant Pathol. 2019, 68, 1059-1071. [CrossRef]

72. Schoelz, J.; Shepherd, R.J.; Daubert, S. Region VI of cauliflower mosaic virus encodes a host range determinant. Mol. Cell. Biol. 1986, 6, 2632-2637. [CrossRef]

73. Eggenberger, A.L.; Hajimorad, M.R.; Hill, J.H. Gain of virulence on Rsv1-genotype soybean by an avirulent Soybean mosaic virus requires concurrent mutations in both P3 and HC-Pro. Mol. Plant Microbe Interact. 2008, 21, 931-936. [CrossRef]

74. Jenner, C.E.; Wang, X.; Tomimura, K.; Ohshima, K.; Ponz, F.; Walsh, J.A. The dual role of the potyvirus P3 protein of Turnip mosaic virus as a symptom and avirulence determinant in brassicas. Mol. Plant Microbe Interact. 2003, 16, 777-784. [CrossRef] 
75. Walsh, J.A.; Jenner, C.E. Turnip mosaic virus and the quest for durable resistance. Mol. Plant. Pathol. 2002, 3, 289-300. [CrossRef]

76. Grech-Baran, M.; Witek, K.; Szajko, K.; Witek, A.I.; Morgiewicz, K.; Wasilewicz-Flis, I.; Jakuczun, H.; Marczewski, W.; Jones, J.D.G.; Hennig, J. Extreme resistance to Potato virus $Y$ in potato carrying the $R y_{\text {sto }}$ gene is mediated by a TIR-NLR immune receptor. Plant Biotechnol. J. 2020, 18, 655-667. [CrossRef]

77. Mestre, P.; Brigneti, G.; Baulcombe, D.C. An Ry-mediated resistance response in potato requires the intact active site of the NIa proteinase from potato virus Y. Plant J. 2000, 23, 653-661. [CrossRef]

78. Mestre, P.; Brigneti, G.; Durrant, M.C.; Baulcombe, D.C. Potato virus Y NIa protease activity is not sufficient for elicitation of Ry-mediated disease resistance in potato. Plant J. 2003, 36, 755-761. [CrossRef]

79. Moffett, P.; Farnham, G.; Peart, J.; Baulcombe, D.C. Interaction between domains of a plant NBS-LRR protein in disease resistance-related cell death. EMBO J. 2002, 21, 4511-4519. [CrossRef]

80. Rairdan, G.J.; Collier, S.M.; Sacco, M.A.; Baldwin, T.T.; Boettrich, T.; Moffett, P. The Coiled-Coil and Nucleotide Binding Domains of the Potato Rx Disease Resistance Protein Function in Pathogen Recognition and Signaling. Plant Cell 2008, $20,739-751$. [CrossRef]

81. Tameling, W.I.; Nooijen, C.; Ludwig, N.; Boter, M.; Slootweg, E.; Goverse, A.; Shirasu, K.; Joosten, M.H. RanGAP2 mediates nucleocytoplasmic partitioning of the NB-LRR immune receptor Rx in the Solanaceae, thereby dictating Rx function. Plant Cell 2010, 22, 4176-4194. [CrossRef]

82. Richard, M.M.; Knip, M.; Schachtschabel, J.; Beijaert, M.S.; Takken, F.L. Perturbation of nuclear-cytosolic shuttling of Rx1 compromises extreme resistance and translational arrest of potato virus X transcripts. Plant J. 2021. [CrossRef] [PubMed]

83. Santa Cruz, S.; Baulcombe, D. Analysis of Potato virus $\mathrm{X}$ coat protein genes in relation to resistance conferred by the genes $\mathrm{Nx}, \mathrm{Nb}$ and Rx1 of potato. J. Gen. Virol. 1995, 76, 2057-2061. [CrossRef] [PubMed]

84. Zhao, Y.; DelGrosso, L.; Yigit, E.; Dempsey, D.A.; Klessig, D.F.; Wobbe, K.K. The amino terminus of the coat protein of Turnip crinkle virus is the AVR factor recognized by resistant arabidopsis. Mol. Plant Microbe Interact. 2000, 13, 1015-1018. [CrossRef] [PubMed]

85. Kang, S.H.; Qu, F.; Morris, T.J. A spectrum of HRT-dependent hypersensitive responses elicited by the 52 amino acid N-terminus of turnip crinkle virus capsid protein and its mutants. Virus Res. 2015, 200, 30-34. [CrossRef]

86. Kang, S.H.; Qu, F.; Morris, T.J. A nuclear fraction of turnip crinkle virus capsid protein is important for elicitation of the host resistance response. Virus Res. 2015, 210, 264-270. [CrossRef]

87. Kuang, H.; Caldwell, K.S.; Meyers, B.C.; Michelmore, R.W. Frequent sequence exchanges between homologs of RPP8 in Arabidopsis are not necessarily associated with genomic proximity. Plant J. 2008, 54, 69-80. [CrossRef]

88. Zhou, X. Advances in understanding begomovirus satellites. Annu. Rev. Phytopathol. 2013, 51, 357-381. [CrossRef]

89. Hull, R. Replication of Plant Viruses. Plant Virol. 2014, 341-421. [CrossRef]

90. Nagy, P.D.; Pogany, J. Global Genomics and Proteomics Approaches to Identify Host Factors as Targets to Induce Resistance Against Tomato Bushy Stunt Virus. In Natural and Engineered Resistance to Plant Viruses: Part II; Carr, J.P., Loebenstein, G., Eds.; Academic Press: Cambridge, MA, USA, 2010; Volume 76, pp. 123-177.

91. Padgett, H.S.; Beachy, R.N. Analysis of a tobacco mosaic virus strain capable of overcoming N gene-mediated resistance. Plant Cell 1993, 5, 577-586.

92. Padgett, H.S.; Watanabe, Y.; Beachy, R.N. Identification of the TMV Replicase Sequence That Activates the N Gene-Mediated Hypersensitive Response. Mol. Plant Microbe Interact. 1997, 10, 709-715. [CrossRef]

93. Feng, Z.; Xue, F.; Xu, M.; Chen, X.; Zhao, W.; Garcia-Murria, M.J.; Mingarro, I.; Liu, Y.; Huang, Y.; Jiang, L.; et al. The ER-Membrane Transport System Is Critical for Intercellular Trafficking of the NSm Movement Protein and Tomato Spotted Wilt Tospovirus. PLoS Pathog. 2016, 12, e1005443. [CrossRef]

94. Lucas, W.J. Plant viral movement proteins: Agents for cell-to-cell trafficking of viral genomes. Virology 2006, 344, 169-184. [CrossRef]

95. Harries, P.A.; Nelson, R.S. Movement of Viruses in Plants. In Encyclopedia of Virology; Mahy, B.W.J., Van Regenmortel, M.H.V., Eds.; Academic Press: Oxford, UK, 2008; pp. 348-355.

96. Lough, T.J.; Lucas, W.J. Integrative plant biology: Role of phloem long-distance macromolecular trafficking. Annu. Rev. Plant Biol. 2006, 57, 203-232. [CrossRef]

97. Zhu, M.; Jiang, L.; Bai, B.; Zhao, W.; Chen, X.; Li, J.; Liu, Y.; Chen, Z.; Wang, B.; Wang, C.; et al. The Intracellular Immune Receptor Sw-5b Confers Broad-Spectrum Resistance to Tospoviruses through Recognition of a Conserved 21-Amino Acid Viral Effector Epitope. Plant Cell 2017, 29, 2214-2232. [CrossRef]

98. Turina, M.; Kormelink, R.; Resende, R.O. Resistance to Tospoviruses in Vegetable Crops: Epidemiological and Molecular Aspects. Annu. Rev. Phytopathol. 2016, 54, 347-371. [CrossRef]

99. Zhu, M.; van Grinsven, I.L.; Kormelink, R.; Tao, X. Paving the Way to Tospovirus Infection: Multilined Interplays with Plant Innate Immunity. Annu. Rev. Phytopathol. 2019, 57, 41-62. [CrossRef]

100. Li, J.; Huang, H.; Zhu, M.; Huang, S.; Zhang, W.; Dinesh-Kumar, S.P.; Tao, X. A Plant Immune Receptor Adopts a Two-Step Recognition Mechanism to Enhance Viral Effector Perception. Mol. Plant 2019, 12, 248-262. [CrossRef]

101. Chen, X.; Zhu, M.; Jiang, L.; Zhao, W.; Li, J.; Wu, J.; Li, C.; Bai, B.; Lu, G.; Chen, H.; et al. A multilayered regulatory mechanism for the autoinhibition and activation of a plant CC-NB-LRR resistance protein with an extra N-terminal domain. New Phytol. 2016, 212, 161-175. [CrossRef] 
102. Zhao, W.; Jiang, L.; Feng, Z.; Chen, X.; Huang, Y.; Xue, F.; Huang, C.; Liu, Y.; Li, F.; Liu, Y.; et al. Plasmodesmata targeting and intercellular trafficking of Tomato spotted wilt tospovirus movement protein NSm is independent of its function in HR induction. J. Gen. Virol. 2016, 97, 1990-1997. [CrossRef]

103. Weber, H.; Ohnesorge, S.; Silber, M.V.; Pfitzner, A.J. The Tomato mosaic virus $30 \mathrm{kDa}$ movement protein interacts differentially with the resistance genes Tm-2 and Tm-2(2). Arch. Virol. 2004, 149, 1499-1514. [CrossRef]

104. Chiu, M.H.; Chen, I.H.; Baulcombe, D.C.; Tsai, C.H. The silencing suppressor P25 of Potato virus X interacts with Argonaute1 and mediates its degradation through the proteasome pathway. Mol. Plant Pathol. 2010, 11, 641-649. [CrossRef]

105. Ding, S.W. RNA-based antiviral immunity. Nat. Rev. Immunol. 2010, 10, 632-644. [CrossRef]

106. Burgyan, J.; Havelda, Z. Viral suppressors of RNA silencing. Trends Plant Sci. 2011, 16, 265-272. [CrossRef]

107. Nakahara, K.S.; Masuta, C. Interaction between viral RNA silencing suppressors and host factors in plant immunity. Curr. Opin. Plant Biol. 2014, 20, 88-95. [CrossRef] [PubMed]

108. Lakatos, L.; Csorba, T.; Pantaleo, V.; Chapman, E.J.; Carrington, J.C.; Liu, Y.P.; Dolja, V.V.; Calvino, L.F.; Lopez-Moya, J.J.; Burgyan, J. Small RNA binding is a common strategy to suppress RNA silencing by several viral suppressors. EMBO J. 2006, 25, 2768-2780. [CrossRef] [PubMed]

109. Azevedo, J.; Garcia, D.; Pontier, D.; Ohnesorge, S.; Yu, A.; Garcia, S.; Braun, L.; Bergdoll, M.; Hakimi, M.A.; Lagrange, T.; et al. Argonaute quenching and global changes in Dicer homeostasis caused by a pathogen-encoded GW repeat protein. Genes Dev. 2010, 24, 904-915. [CrossRef]

110. Zhang, X.; Yuan, Y.-R.; Pei, Y.; Lin, S.-S.; Tuschl, T.; Patel, D.J.; Chua, N.-H. Cucumber mosaic virus-encoded 2b suppressor inhibits Arabidopsis Argonaute1 cleavage activity to counter plant defense. Genes Dev. 2006, 20, 3255-3268. [CrossRef]

111. Liu, J.-Z.; Li, F.; Liu, Y. Editorial: Plant Immunity against Viruses. Front. Microbiol. 2017, 8, 520. [CrossRef]

112. Zvereva, A.S.; Pooggin, M.M. Silencing and innate immunity in plant defense against viral and non-viral pathogens. Viruses 2012, 4, 2578-2597. [CrossRef]

113. Niehl, A.; Heinlein, M. Perception of double-stranded RNA in plant antiviral immunity. Mol. Plant Pathol. 2019, 20, 1203-1210. [CrossRef] [PubMed]

114. Hedil, M.; de Ronde, D.; Kormelink, R. Biochemical analysis of NSs from different tospoviruses. Virus Res. 2017, 242, 149-155. [CrossRef]

115. Schnettler, E.; Hemmes, H.; Huismann, R.; Goldbach, R.; Prins, M.; Kormelink, R. Diverging affinity of tospovirus RNA silencing suppressor proteins, NSs, for various RNA duplex molecules. J. Virol. 2010, 84, 11542-11554. [CrossRef]

116. De Ronde, D.; Pasquier, A.; Ying, S.; Butterbach, P.; Lohuis, D.; Kormelink, R. Analysis of Tomato spotted wilt virus NSs protein indicates the importance of the N-terminal domain for avirulence and RNA silencing suppression. Mol. Plant Pathol. 2014, 15, 185-195. [CrossRef]

117. Derrien, B.; Baumberger, N.; Schepetilnikov, M.; Viotti, C.; De Cillia, J.; Ziegler-Graff, V.; Isono, E.; Schumacher, K.; Genschik, P. Degradation of the antiviral component ARGONAUTE1 by the autophagy pathway. Proc. Natl. Acad. Sci. USA 2012, 109, 15942-15946. [CrossRef]

118. Garcia, J.A.; Pallas, V. Viral factors involved in plant pathogenesis. Curr. Opin. Virol. 2015, 11 (Suppl. C), 21-30. [CrossRef]

119. Garcia-Ruiz, H. Host factors against plant viruses. Mol. Plant Pathol. 2019, 20, 1588-1601. [CrossRef]

120. Cole, A.B.; Kiraly, L.; Ross, K.; Schoelz, J.E. Uncoupling resistance from cell death in the hypersensitive response of Nicotiana species to cauliflower mosaic virus infection. Mol. Plant Microbe Interact. 2001, 14, 31-41. [CrossRef]

121. Király, L.; Cole, A.B.; Bourque, J.E.; Schoelz, J.E. Systemic Cell Death Is Elicited by the Interaction of a Single Gene in Nicotiana clevelandii and Gene VI of Cauliflower Mosaic Virus. Mol. Plant Microbe Interact. 1999, 12, 919-925. [CrossRef]

122. Leisner, S.M.; Schoelz, J.E. Joining the Crowd: Integrating Plant Virus Proteins into the Larger World of Pathogen Effectors. Annu. Rev. Phytopathol. 2018, 56, 89-110. [CrossRef]

123. Broglio, E.P. Mutational analysis of cauliflower mosaic virus gene VI: Changes in host range, symptoms, and discovery of transactivation-positive, noninfectious mutants. Mol. Plant Microbe Interact. 1995, 8, 755-760. [CrossRef]

124. Bonneville, J.M.; Sanfacon, H.; Futterer, J.; Hohn, T. Posttranscriptional trans-activation in cauliflower mosaic virus. Cell 1989, 59, 1135-1143. [CrossRef]

125. Zvereva, A.S.; Golyaev, V.; Turco, S.; Gubaeva, E.G.; Rajeswaran, R.; Schepetilnikov, M.V.; Srour, O.; Ryabova, L.A.; Boller, T.; Pooggin, M.M. Viral protein suppresses oxidative burst and salicylic acid-dependent autophagy and facilitates bacterial growth on virus-infected plants. New Phytol. 2016, 211, 1020-1034. [CrossRef] [PubMed]

126. Harries, P.A.; Palanichelvam, K.; Yu, W.; Schoelz, J.E.; Nelson, R.S. The cauliflower mosaic virus protein P6 forms motile inclusions that traffic along actin microfilaments and stabilize microtubules. Plant Physiol. 2009, 149, 1005-1016. [CrossRef] [PubMed]

127. Angel, C.A.; Lutz, L.; Yang, X.; Rodriguez, A.; Adair, A.; Zhang, Y.; Leisner, S.M.; Nelson, R.S.; Schoelz, J.E. The P6 protein of Cauliflower mosaic virus interacts with CHUP1, a plant protein which moves chloroplasts on actin microfilaments. Virology 2013, 443, 363-374. [CrossRef]

128. Schoelz, J.E.; Angel, C.A.; Nelson, R.S.; Leisner, S.M. A model for intracellular movement of Cauliflower mosaic virus: The concept of the mobile virion factory. J. Exp. Bot. 2016, 67, 2039-2048. [CrossRef]

129. Palanichelvam, K.; Schoelz, J.E. A comparative analysis of the avirulence and translational transactivator functions of gene VI of Cauliflower mosaic virus. Virology 2002, 293, 225-233. [CrossRef] 
130. Agama, K.; Beach, S.; Schoelz, J.; Leisner, S.M. The 5' Third of Cauliflower mosaic virus Gene VI Conditions Resistance Breakage in Arabidopsis Ecotype Tsu-0. Phytopathology 2002, 92, 190-196. [CrossRef]

131. Wen, R.H.; Khatabi, B.; Ashfield, T.; Saghai Maroof, M.A.; Hajimorad, M.R. The HC-Pro and P3 cistrons of an avirulent Soybean mosaic virus are recognized by different resistance genes at the complex Rsv1 locus. Mol. Plant Microbe Interact. 2013, 26, 203-215. [CrossRef]

132. Tran, P.T.; Choi, H.; Kim, S.B.; Lee, H.A.; Choi, D.; Kim, K.H. A simple method for screening of plant NBS-LRR genes that confer a hypersensitive response to plant viruses and its application for screening candidate pepper genes against Pepper mottle virus. J. Virol. Methods 2014, 201, 57-64. [CrossRef]

133. Selisana, S.M.; Yanoria, M.J.; Quime, B.; Chaipanya, C.; Lu, G.; Opulencia, R.; Wang, G.L.; Mitchell, T.; Correll, J.; Talbot, N.J.; et al. Avirulence (AVR) Gene-Based Diagnosis Complements Existing Pathogen Surveillance Tools for Effective Deployment of Resistance (R) Genes Against Rice Blast Disease. Phytopathology 2017, 107, 711-720. [CrossRef]

134. Vallejos, C.E.; Astua-Monge, G.; Jones, V.; Plyler, T.R.; Sakiyama, N.S.; Mackenzie, S.A. Genetic and Molecular Characterization of the I Locus of Phaseolus vulgaris. Genetics 2006, 172, 1229-1242. [CrossRef]

135. Vidal, S.; Cabrera, H.; Andersson, R.A.; Fredriksson, A.; Valkonen, J.P.T. Potato Gene $Y-1$ is an N Gene Homolog That Confers Cell Death Upon Infection with potato virus Y. Mol. Plant Microbe Interact. 2002, 15, 717-727. [CrossRef]

136. Brotman, Y.; Normantovich, M.; Goldenberg, Z.; Zvirin, Z.; Kovalski, I.; Stovbun, N.; Doniger, T.; Bolger, A.M.; Troadec, C.; Bendahmane, A.; et al. Dual Resistance of Melon to Fusarium oxysporum Races 0 and 2 and to Papaya ring-spot virus is Controlled by a Pair of Head-to-Head-Oriented NB-LRR Genes of Unusual Architecture. Mol. Plant 2013, 6, 235-238. [CrossRef]

137. Rai, M. Refinement of the Citrus Tristeza Virus Res.istance Gene (Ctv) Positional Map in Poncirus trifoliata and Generation of Transgenic Grapefruit (Citrus paradisi) Plant Lines with Candidate Resistance Genes in this Region. Plant Mol. Biol. 2006, 61, 399-414. [CrossRef]

138. Ma, J.; Hou, X.; Xiao, D.; Qi, L.; Wang, F.; Sun, F.; Wang, Q. Cloning and Characterization of the BcTuR3 Gene Related to Resistance to Turnip Mosaic Virus (TuMV) from Non-heading Chinese Cabbage. Plant Mol. Biol. Rep. 2010, 28, 588-596. [CrossRef]

139. Caplan, J.L.; Mamillapalli, P.; Burch-Smith, T.M.; Czymmek, K.; Dinesh-Kumar, S.P. Chloroplastic protein NRIP1 mediates innate immune receptor recognition of a viral effector. Cell 2008, 132, 449-462. [CrossRef]

140. Chen, T.; Liu, D.; Niu, X.; Wang, J.; Qian, L.; Han, L.; Liu, N.; Zhao, J.; Hong, Y.; Liu, Y. Antiviral Resistance Protein Tm-2 ${ }^{(2)}$ Functions on the Plasma Membrane. Plant Physiol. 2017, 173, 2399-2410. [CrossRef]

141. Du, Y.; Zhao, J.; Chen, T.; Liu, Q.; Zhang, H.; Wang, Y.; Hong, Y.; Xiao, F.; Zhang, L.; Shen, Q.; et al. Type I J-domain NbMIP1 proteins are required for both Tobacco mosaic virus infection and plant innate immunity. PLoS Pathog. 2013, 9, e1003659. [CrossRef]

142. Zhang, Y.; Song, G.; Lal, N.K.; Nagalakshmi, U.; Li, Y.; Zheng, W.; Huang, P.J.; Branon, T.C.; Ting, A.Y.; Walley, J.W.; et al. TurboID-based proximity labeling reveals that UBR7 is a regulator of N NLR immune receptor-mediated immunity. Nat. Commun. 2019, 10, 3252. [CrossRef]

143. Mishra, B.; Kumar, N.; Mukhtar, M.S. Systems Biology and Machine Learning in Plant-Pathogen Interactions. Mol. Plant Microbe Interact. 2019, 32, 45-55. [CrossRef]

144. Wang, J.; Hu, M.; Wang, J.; Qi, J.; Han, Z.; Wang, G.; Qi, Y.; Wang, H.-W.; Zhou, J.-M.; Chai, J. Reconstitution and structure of a plant NLR resistosome conferring immunity. Science 2019, 364, eaav5870. [CrossRef]

145. Wang, J.; Wang, J.; Hu, M.; Wu, S.; Qi, J.; Wang, G.; Han, Z.; Qi, Y.; Gao, N.; Wang, H.-W.; et al. Ligand-triggered allosteric ADP release primes a plant NLR complex. Science 2019, 364, eaav5868. [CrossRef]

146. Ma, S.; Lapin, D.; Liu, L.; Sun, Y.; Song, W.; Zhang, X.; Logemann, E.; Yu, D.; Wang, J.; Jirschitzka, J.; et al. Direct pathogen-induced assembly of an NLR immune receptor complex to form a holoenzyme. Science 2020, 370, eabe3069. [CrossRef]

147. Martin, R.; Qi, T.; Zhang, H.; Liu, F.; King, M.; Toth, C.; Nogales, E.; Staskawicz, B.J. Structure of the activated ROQ1 resistosome directly recognizing the pathogen effector XopQ. Science 2020, 370, eabd9993. [CrossRef]

148. De Oliveira, A.S.; Koolhaas, I.; Boiteux, L.S.; Caldararu, O.F.; Petrescu, A.J.; Oliveira Resende, R.; Kormelink, R. Cell death triggering and effector recognition by Sw-5 SD-CNL proteins from resistant and susceptible tomato isolines to Tomato spotted wilt virus. Mol. Plant Pathol. 2016, 17, 1442-1454. [CrossRef] 